\title{
Tokoh Kabayan Sebagai Inspirasi Torotot Heong the Song of Kabayan
}

\author{
DEDEN HAERUDIN
}

Jurusan Seni Tari, Fakultas Bahasa dan Seni, Universitas Negeri Jakarta

\begin{abstract}
Kabayan as an Inspiration of Torotot Heong The Song Of Kabayan. The theater art creation of Torotot Heong the Song of Kabayan is a process that is inspired by the characters of folklore in Sundanese literature, Kabayan. In Sundanese society, Kabayan is a stunt character from parable, a symbolic story, in the community as a media to notify precept or wisdom. Kabayan is regarded as character with characteristic of Sundanese culture that hold on to "Cageur jeung Bageur" living guide (hale and healthy, and kind hearted). The creation process of Torotot Heong the Song of Kabayan is performing into several stages and working methods according to Patri Pavis. It is started by selecting the Kabayan's Story to under take into the script. The next stage is doing some preparation for Staging Process. The creating process is conducted through the mise en scene show's appearance, perform into idea identification stage, artistic observation of cultural resources, the artist perspective and performance realization. Torotot Heong the Song of Kabayan performances are the ultimate stage for the creative process of the hardworking team with a lot of effort to accomplish a communicative performance and appreciate well by the audience.
\end{abstract}

Key words: Kabayan, Torotot Heong, consumerism, mise en scene, appreciation.

\section{Pendahuluan}

"Torotot Heong the Song of Kabayan", judul karya seni Teater ini berasal dari perpaduan kata bahasa Sunda "Torotot Heong", secara etimologis tidak mengandung arti apapun, tetapi hanya mewakili bunyi, yaitu bunyi suling. Kata "The Song Of Kabayan" dalam bahasa Inggris artinya menjadi "nyanyian tentang Kabayan". Secara keseluruhan Torotot Heong the Song of Kabayan dapat dimaknai sebagai pertunjukan teater yang merupakan nyanyian berisi cerita kehidupan tentang Kabayan.

Latar budaya masyarakat Jawa Barat sangat terbuka terhadap berbagai pengaruh budaya luar, hal ini terbukti dengan banyaknya artefak peninggalan Hindu-Budha maupun peninggalan Islam di berbagai daerah. Pengaruh kebudayaan Islam mulai mengakar di Jawa Barat sejak abad ke-17. Hal ini dapat dilihat dari peninggalan beberapa karya naskah kuno yang mengandung ajaran keislaman. Pada umumnya naskah-naskah yang dipengaruhi budaya Islam tersebut mengandung ajaran agama, susila, hukum, adat istiadat, mitologi, ilmu pengetahuan, sastra, dan seni.

Pemahaman ajaran Islam lewat karya sastra, pada masyarakat Sunda tidak lepas dari peranan para ulama. Dengan kreativitas yang dimiliki oleh para ulama, ajaran Islam ditranformasikan dengan kekayaan budaya setempat, sehingga melahirkan karya-karya yang unik dan menarik. Masyarakat Sunda mengenal tokoh Amir Hamzah, Abu Nawas dan tokoh-tokoh kesusastraan Islam Timur Tengah. Para Ulama Sunda menyadari di tengah masyarakat yang belum mampu memproduksi buku, maka sistem dakwah bil hal melalui pendekatan budaya akan lebih dinikmati oleh masyarakat luas daripada dalil Al Qur'an dan Hadis. Kalau ajaran Al Qur'an penuh dengan pesan tersirat atau cryptical message ulama Sunda pun berupaya membuat pesan siloka atau simbol yang berupa bahasa dan barang (Mansur, 1998: 73).

Khasanah cerita Kabayan, menurut Jakob Sumarjo lahir dari kalangan pesantren-pesantren

\footnotetext{
*Alamat korespondensi: Kampus A Gd. S Lantai Dasar UNJ, Jln. Rawamangun Muka, Jakarta Timur 13220, Tlp. 021-4710547. HP: 08128716554,e-mail: rengga_bdg@yahoo.co.id
} 
di wilayah Banten, yaitu dari kreativitas kaum tasawuf dalam menyebarkan ajaran-ajaran tentang kemakrifatan hidup dengan menggunakan siloka atau simbol. Cerita-cerita Kabayan bersifat paradoksal artinya pembacaan cerita Kabayan dapat dibaca dalam dua sisi, yaitu secara awam kita mengena pembacaan secara lugas apa adanya, eksoterik. Sedangkan sisi lainnya adalah pembacaan yang memerlukan bekal pengetahuan budaya, filsafat dan mistikisme. Biasanya terjadi di lingkungan komunitas tertutup dan terbatas, esoterik. (Sumardjo, 2008: 8).

Kamus Bahasa Naskah dan Prasasti Sunda abad ke-11 sampai dengan abad ke-18, Kata "Kabayan" artinya pesuruh, tua (Ekadjati, 2001:83). Beberapa tokoh seniman Sunda memberikan pemaknaan terhadap nama 'Kabayan'. Seperti yang diungkapkan oleh Yusef Muldiyana, 'Kabayan' artinya Duta atau utusan, " $\mathrm{Ka}$ " artinya menuju, sedangkan "bayan" artinya ajaran, wejangan. Sedangkan Wawan Husen berpendapat bahwa kata Kabayan disejajarkan dengan istilah babarayaan artinya keakraban, kekeluargaan. (Wawancara 12 Pebruari 2009, Bandung). Dari kedua ungkapan tersebut kita dapat melihat bahwa di balik nama Kabayan terkandung makna filosofis yang terkandung dalam masyarakat sunda.

\section{Ide Penciptaan}

Torotot Heong the Song of Kabayan merupakan lakon yang terinspirasi oleh karakter seorang tokoh sastra lama budaya Sunda yaitu Kabayan. Tokoh dan karakter yang terdapat dalam cerita Kabayan ditransformasi pada permasalahan masa kini dengan menyoroti perubahan sosial dan budaya yang terjadi dalam masyarakat, khususnya masyarakat sunda. Perkembangan industri dan teknologi informatika telah membawa perubahan sikap hidup dan perilaku sosial, yang menciptakan budaya konsumerisme. Kemajuan ekonomi sekarang ini menyebabkan berkembangnya berbagai gaya hidup, sebagai bukti diferensiasi sosial yang tercipta dari relasi konsumsi. Perubahan tersebut, mengidentifikasikan bahwakonsumsi tidak lagi sekedar berkaitan dengan nilai guna untuk memenuhi kebutuhan dasar manusia tertentu, akan tetapi berkaitan dengan unsur-unsur simbolik untuk menandai kelas, status, atau simbol sosial tertentu. Konsumsi mengekspresikan posisi sosial dan identitas kultural seseorang dalam masyarakat.
Sedangkan yang dikonsumsi tidak lagi sekedar objek, tetapi makna-makna sosial yang tersembunyi di dalamnya. Seperti apakah perjuangan "manusiamanusia Kabayan" dalam menempatkan posisinya di tengah-tengah pergerakan ekonomi kapitalisme global? Bisakah kesederhanaan, kejujuran dan kepolosan "manusia-manusia Kabayan" menjadi pemenang dan selamat dari budaya konsumsi. Berangkat dari permasalahan di atas maka dirumuskan ide penciptaan sebagai berikut: "Bagaimana mewujudkan lakon Torotot Heong the Song of Kabayan ke dalam sebuah pemanggungan teater kontemporer dengan penggunaan spektakel dan idiom-idiom yang mutakhir".

Selain itu, penulis akan memunculkan sosok Kabayan yang hidup dalam jiwa yang mengalir bersama hiruk pikuk kehidupan sosial, budaya, dengan muatan gagasan yang menekankan pada situasi perubahan psikokultural yang diusung oleh serbuan budaya konsumsi. Pada situasi demikian, setiap orang kehilangan identitas kultur dan tradisinya, Sehingga tidak ada apapun selain hasrat dan tanpa pernah tahu apa sebenarnya dibalik hasrat itu.

Proses penciptaan Torotot Heong the Song of Kabayan ini khususnya pada proses pembuatan naskah dan pemanggungan, terinspirasi oleh teater gaya Bertold Brecht. Brecht mengemukakan tiga prinsip utama yaitu; historifikasi, alienasi, dan epik (Sumarjo, 1986: 99). Historifikasi merupakan prinsip bahwa teater harus berbeda dengan kehidupan sehari-hari. Teater harus menyajikan sesuatu yang tidak biasa yang aneh dan asing, lain dari kenyataan sehari-hari. Dengan historifikasi, Brecht berharap penonton dapat mengambil jarak dari yang ditontonnya dan dapat mengambil sikap positif terhadap persoalan yang dipaparkan di atas pentas. Verfremdung effect (disingkat $V$-effect) atau efek alienasi (pengasingan) merupakan dasar historifikasi, penonton tidak boleh mencampuradukkan antara apa yang terjadi di pentas dengan kenyataan hidupnya, bahkan mengingatnya pun tidak boleh. Pentas hanya tontonan yang mesti dihadapi dengan kritis. Melalui alienasi inilah penonton dapat memperoleh hiburan yang lebih tinggi berupa partisipasi. Epik secara sengaja dipakai untuk menamai teater Brecht, sebab teaternya lebih mirip cerita-cerita epos. 
Konsep Brecht dengan teater epik dan $V$-effek, sejalan dengan semangat teater tradisional pada umumnya. Teater rakyat Jawa Barat, karena teater rakyat menurut Saini KM kekuatan utamanya ada pada teatrikalitasnya yaitu menampilkan "teater sebagai teater" bukannya menampilkan kehidupan ditiru secara detail. Maka, dalam perwujudannya teater rakyat kita selalu digayakan dan didistorsi. Musikalitas, pengolahan gerak menjadi irama dan dinamika pertunjukan teater rakyat (Saini, 1988:72).

\section{Lakon Komedi}

Lakon cerita-cerita Kabayan, secara umum masuk dalam bentuk komedi, untuk itu diperlukan pemahaman sejarah dan seluk beluk mengenai komedi ini. Komedi, sebagai sebuah bentuk lakon dalam sejarah lahir tidak terlalu jauh dengan bentuk tragedi, yaitu sekitar $442 \mathrm{SM}$. Komedi lahir sebagai bagian dari upacara keagamaan orang-orang Yunani kuno dalam menghormati dewa anggur dan dewa kesuburan mereka, Dionysius. Awalnya yang disebut sebagai komedi belum merupakan sebuah pertunjukan yang menampilkan cerita atau kisah, tetapi masih berupa arak-arakan para aktor yang memakai kostum binatang, bernyanyi sambil melontarkan parodi-parodi dan kata-kata yang menimbulkan tertawaan penonton, sampai akhirnya komedi juga menampilkan unsur plot seperti yang kita saksikan sekarang. Komedi adalah salah satu bentuk lakon pertunjukan yang mengandung banyak hal atau peristiwa tentang tokoh-tokoh tertentu yang menimbulkan kelucuan. Lakon komedi sering dipakai sebagai media perlawanan dari pengarangnya terhadap situasi dan permasalahan zaman yang dihadapinya dengan harapan adanya perubahan yang dapat memberikan pencerahan bagi lingkungan dan masyarakat sekitarnya menuju tataran yang lebih baik lagi.

Lakon Torotot Heong the Song of Kabayan, dibuat menjadi sebuah naskah yang menampilkan kelucuan bukan dari gerak fisikal atau komikal yang slapstik, tetapi lebih membuat kelucuan dari logika bahasa dan situasi komedi. Hal ini sesuai dengan pendapat George Meredith dalam Sembung (1983 : 25) yang mengungkapkan istilah komedi tinggi. Komedi tinggi adalah komedi yang mempunyai ciri-ciri sebagai berikut: (1) Mempergunakan perkataan-perkataan atau bahasa yang baik dan sopan, (2) Konflik atau kekacauankekacauannya tidak bersandar pada aksi-aksi fisik yang keras dan kasar, (3) Melibatkan masalahmasalah yang lebih berbobot, seperti masalah sosial, politik, ideologi, moral, kejiwaan dan lainlain. Pada prinsipnya bukan merupakan masalah yang remeh-temeh yang tidak mengundang pemikiran cukup serius ketika menikmatinya, (4) Melibatkan perkembangan-perkembangan, baik peristiwa, sikap atau keadaan tokoh lebih logis dan masuk akal, lebih intelektual.

Torotot Heong the Song of Kabayan, diharapkan menjadi komedi penuh dengan humor. Sesudah kita tertawa, kita diajak berpikir, merenungkan isi kandungan humornya itu, kemudian disusul dengan berbagai macam pertanyaan yang relevan. Akhirnya, kita dapat mawas diri, menilai kelemahan, kekuatan, mengkritik dan berdialog sendiri serta mentertawakan diri sendiri sekaligus mengkritisi kondisi lingkungan sosial untuk mencari solusi.

Tema sosial budaya adalah tema yang ditampilkan pada garapan Torotot Heong the Song of Kabayan, dengan karakter tokoh Kabayan serta tokoh-tokoh yang terdapat dalam naskah yang dijadikan sebagai representasi kelompok sosial budaya dalam budaya Sunda yang sedang terguncang identitasnya di tengah-tengah pergulatan budaya konsumsi.

Fokus pertunjukan tidak menekankan pada narasi dan konflik para tokohnya melainkan konflik yang dihadirkan dijadikan sebagai suasana ketika identitas berada di tengah perubahan, dimana manusia di dalamnya terperangkap dalam budaya konsumsi masyarakat urban yang meniadakan identitas apapun. Di sinilah keluguan dan kenaifan Kabayan hidup dan dipertaruhkan.

\section{Konsep Garapan Torotot Heong the Song of Kabayan.}

Torotot Heong The Song Of Kabayan, secara konsep menampilkan keunikan karakter tokoh Kabayan yang konyol, pintar, cerdik dan beruntung. Pemasalahan 'kekinian' yang aktual menjadi konfik utama yang akan menghidupkan pemanggungan. Konsep panggung dengan penggunaan multi media sebagai bagian spektakel, menjadikan Torotot Heong The Song Of Kabayan sebagai pertunjukan mutakhir. Penguasaan teknik 
pemeranan dari pendukung yang memainkan tokoh-tokoh karakter dalam cerita sangat menentukan keberhasilan garapan ini. Unsur musik, nyanyian, tarian serta gerak kreatif yang menarik merupakan jalinan yang utuh dengan permainan para aktor.

Materi cerita merupakan naskah yang dibuat oleh penulis. Karakter tokoh Kabayan menjadi sentral dalam keseluruhan adegan, konflik dibangun oleh keunikan tokoh Kabayan dalam menghadapi permasalahan kehidupannya. Muatan permasalahan terdiri dari permasalahanpermasalahan kekinian, seperti budaya konsumerisme, kapitalisme dan absurditas manusia mengejar mimpi-mimpi dunia televisi. Kondisi permasalahan tersebut penulis benturkan dengan kepolosan, keluguan dan kecerdikan tokoh Kabayan, sehingga terbangun rangkaian cerita satire, yang membuat penonton tergelitik dengan tingkah polah tokoh-tokoh sebagai gambaran situasi yang terjadi saat ini. Plot atau alur cerita, secara struktur menggunakan jenis plot episodik, yaitu alur cerita tidak bergerak lurus dari A sampai $Z$, tetapi tiap adegan atau episode cerita menampilkan suasana permasalahan sendiri dan berdiri sendiri. Benang merah keseluruhan alur diikat oleh karakter tokoh kabayan. Adeganadegan diberi variasi dengan permainan rakyat, lagu dan tarian rakyat Sunda, sehingga permainan dapat tampil menarik dan tidak membosankan.

Proses kerja penciptaan teater Torotot Heong the SongofKabayan ditempuh dalam beberapa tahapan dan metode kerja seperti yang dikemukakan Patrice Pavis. Tahapan diawali dengan menyeleksi

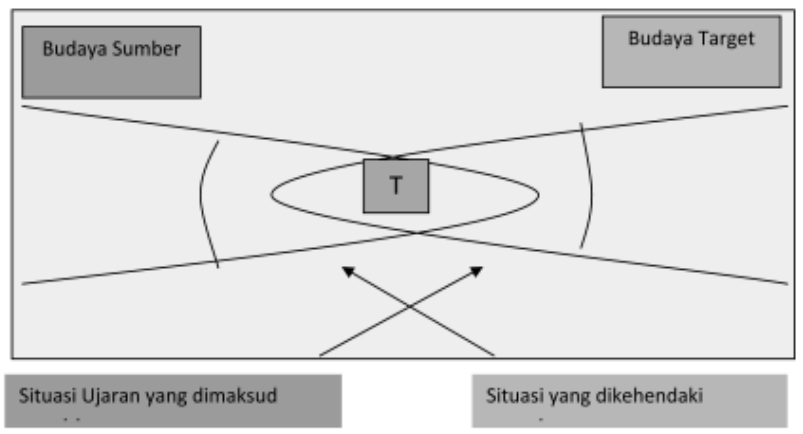

cerita-cerita Kabayan untuk diwujudkan ke dalam sebuah naskah pentas. Selanjutnya dilakukan berbagai persiapan yang mengarah pada proses pemanggungan. Pavis menjelaskan proses metode penciptaan dalan skema dibawah ini :
Wilayah T sebagai mise en scene atau wilayah pertemuan antara situasi yang dikehendaki pengirim dengan situasi yang dikehendaki penerima. Teks kebudayaan Sunda berupa cerita-cerita Kabayan sebagai idiom atau budaya sumber,

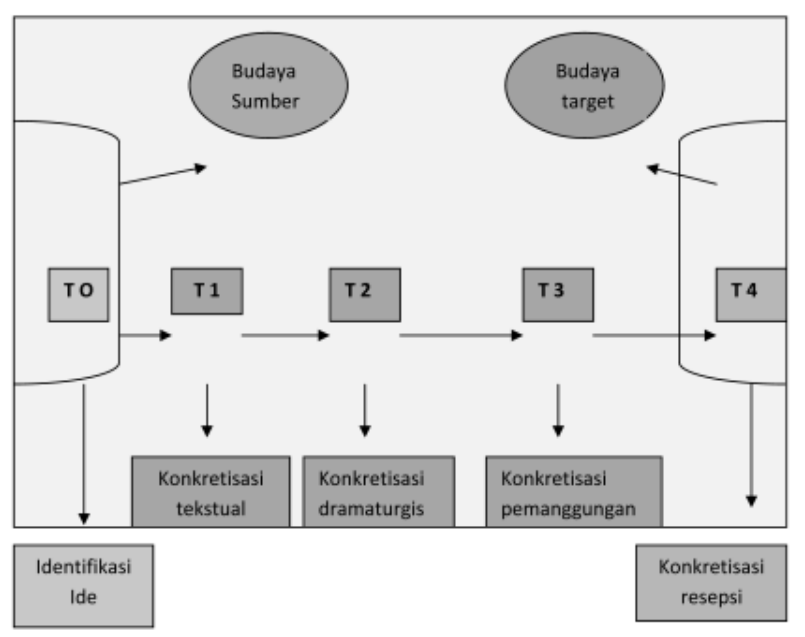

ditranformasikan dalam suasana sekarang sebagai budaya target $(\mathrm{T})$. Rantai pertemuan budaya sumber dan budaya target $(\mathrm{T})$ dalam proses penciptaan digarap melalui pembentukan mise en scene pertunjukan juga berlangsung dalam tahapan sebagai berikut:

Tahap pertama (TO), yaitu identifikasi ide, menuliskan sinopsis dan treatment cerita Torotot Heong the Song of Kabayan yang akan dipentaskan berdasarkan studi pustaka dan perumusan konsepsi. Bahan yang didapat pada proses ini adalah beberapa buku yang menuliskan cerita lisan Kabayan, artikel dan majalah-majalah lama.

Tahap kedua (T1) yaitu observasi artistik budaya sumber. Pada tahap ini, penulis melakukan wawancara di wilayah budaya Sunda pada beberapa tokoh Sunda tentang budaya dan karakteristik manusia sunda, sampai mendapatkan gambaran yang jelas mengenai sosok dan karakteristik Kabayan serta filosofis yang sangat mendasar dari tokoh kabayan, "Teu nanaon ku nanaon "(tidak apa-apa oleh apapun).

Tahap ketiga (T2) yaitu perspektif seniman. Tahapan ini merupakan kongkretisasi dramaturgi yang menempatkan naskah Torotot Heong the Song of Kabayan dari tradisi lisan dan diolah dengan permasalahan kondisi masa kini, diwujudkan dalam elemen artistik pemanggungan kontemporer dengan memadukan konsep teater rakyat Jawa Barat pada konsepsi teater Brech. 
Tahap Keempat (T3), Kongkretisasi pemanggungan. Torotot Heong the Song of Kabayan dikemas sebagai sebuah pertunjukan teater kontemporer yang mentransformasikan idiom-idiom tradisional Sunda dengan pendekatan Teater Modern, ada dialog interkontekstual antara budaya lama dengan budaya yang sedang terjadi saat ini sehingga memunculkan potret budaya yang mewarnai perjalanan budaya manusia Sunda. Pertunjukan ditampilkan di lingkungan pendukung budaya Sunda seperti di daerah Jawa Barat, tepatnya di kota Bandung. Produksi pertunjukan ditangani dengan manajemen produksi teater modern. Jenis panggung yang dipilih adalah panggung prosenium .

Tahap Kelima (T4) konkretisasi resepsi. Torotot Heong the Song of Kabayan adalah sebuah pertunjukan teater yang memberikan warna dan tafsir baru terhadap karakter tokoh Kabayan, mengandung muatan kritik tentang kehidupan sosial dan budaya yang terjadi di masyarakat saat ini. Keberhasilan komunikasi pertunjukan Torotot Heong the Song of Kabayan, ditentukan oleh tingkat apresiasi penonton yang sesuai. Penonton yang diharapkan adalah penonton dewasa dari kalangan pemerhati budaya, seniman, mahasiswa dan masyarakat umum yang mempunyai kepekaan terhadap permasalahan lingkungan sosial.

\section{Penutup}

Proses menciptakan sebuah karya seni adalah suatu proses yang panjang dengan kompleksitas permasalahan yang unik dan menarik untuk dilalui. Proses penciptaan karya seni teater berjudul Torotot Heong the Song of Kabayan, merupakan perjalanan proses yang dimulai dari eksplorasi terhadap kekayaan budaya dalam kesusastraan Sunda lama, yaitu sastra lisan tentang cerita-cerita Kabayan yang beredar di kalangan masyarakat. Selain juga dikumpulkan referensi dari berbagai sumber maupun pendapat tokoh masyarakat mengenai eksistensi Kabayan dalam budaya masyarakat Sunda.

Cerita-cerita Kabayan yang beredar di kalangan masyarakathanyaberupasketsa-sketsaceritapendek dan lepas, sehingga memerlukan keterampilan untuk menyusun dan mengembangkan cerita menjadi sebuah naskah teater yang menarik untuk dimainkan. Untuk mewujudkan naskah cerita Kabayan menjadi adegan-adegan yang hidup, diperlukan kecermatan dalam memilih pemain pendukung, baik pemeran maupun kerabat kerja artistik.

\section{Kepustakaan}

Anirun, Suyatna. 1993. Teater untuk Dilakoni. Bandung: Penerbit STB. .1998, Menjadi Aktor, Bandung: Penerbit STB dan Taman Budaya Jawa Barat,. . 2003. Menjadi Sutradara, Bandung: Penerbit STSI Press.

Cohen, Robert. 1983. Theatre, USA: Mayfield Publishing Company.

Dahana, Radhar Panca. 2001. Homo Theatricus, Magelang: Indonesiatera.

Djelantik A.A.M. 1989. Estetika Sebuah Pengantar, Yogyakarta: MSPI dan Arti Line.

Ekadjati, Edi S. 2001. Kamus Bahasa Naskah dan Prasasti Sunda Abad 11 sampai dengan 18, Pernaskahan Sunda Purbatisti dan Pemerintah Kota Bandung.

Kernoddle, George.R. 1967. Invitation of the Theatre, USA: Harcourt, Brace \& World Inc.

Mansur, Suryanegara, Ahmad. 1998. Transformasi Nilai Islam Dalam Budaya Sunda, Yogyakarta: SMF Adab Sunan Kalijaga.

Miharja, Achdiat K. 1997. Kabayan Manusia Lucu, Jakarta: Grasindo.

Piliang,Yasraf Amir. 2007. Dunia yang dilipat, Jogyakarta: Jalasutra.

Rosidi, Ajip. 1984. Manusia Sunda, Jakarta: Inti Idayu Press.

Saini KM. 1988. Teater Modern Indonesia dan Beberapa Masalahnya, Bandung: Binacipta.

Sembung, Willy F. 1983. "Pengetahuan tentang bentuk-bentuk lakon", Proyek Pengembangan Institut Kesenian Indonesia Sub Proyek Akademi Seni Tari Indonesia Bandung.

Sumarjo, Jakob. 1986. Ikhtisar Sejarah Teater Barat, Bandung: Penerbit Angkasa. bit ITB. 2000. Filsafat Seni, Bandung: PenerSunan Ambu Press. 2008. Paradok Cerita-Cerita Kabayan, Bandung: Kelir.

2003. Simbol-Simbol Artefak Budaya Sunda, Bandung: Kelir. 
Yudiaryani. 2003. Panggung Teater Dunia. Yogyakarta: Pustaka Gondosuli.

\section{Narasumber}

Husin, Wawan (65 th), Penulis dan Budayawan, wawancara tanggal 12 Pebruari 2009, di Gedung Kesenian Rumentang Siang Bandung.
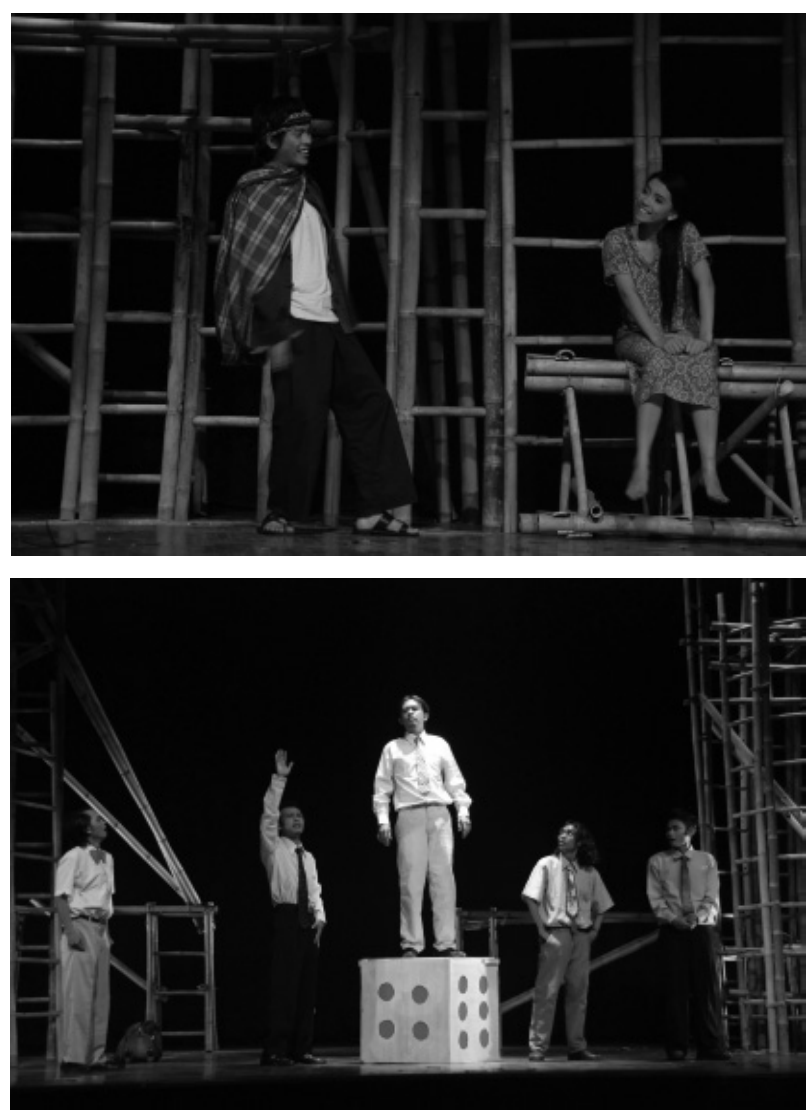

Muldiyana, Yusef (50 th), Penulis naskah dan Teatrawan, wawancara tanggal 12 Pebruari 2009 di Gedung Kesenian Rumentang Siang Bandung.

\section{Lampiran:}

Foto-foto pertunjukan Torotot Heong the Song of Kabayan
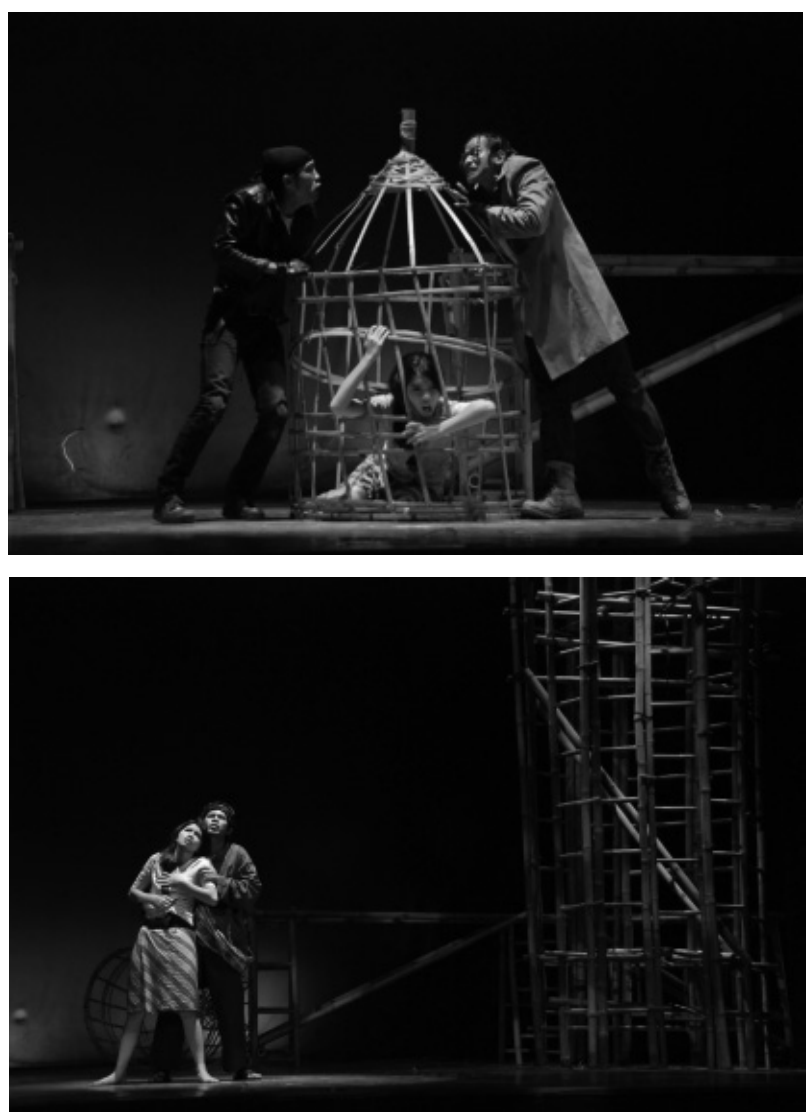